\title{
Muslim Pop: Voicing $D a$ 'wa through Contemporary English Nasyid Love Song Lyrics in Southeast Asia
}

\author{
Maria Ulfa \\ English Language and Literature Department \\ Syarif Hidayatullah State Islamic University Jakarta, Indonesia \\ maria.ulfa@uinjkt.ac.id
}

\begin{abstract}
This paper examines nasyid English love song lyrics in Southeast Asia, in particular from Malaysian nasyid group named Raihan and Indonesian Nasyid group named Snada. Both are the icons of Southeast Asian nasyid groups. In their song albums, they have some English lyrics and one of the song lyrics is about religious love theme. The English lyrics are used particularly to reach the international audience. Therefore, this research tries to examine their lyrics as English poems namely "Bonds of Love" by Raihan and "Highest Love" by Snada in order to understand, explore, and explain the meanings of the lyrics through some elements of poetry namely meaning \& idea, form, speaker (point of view), listener/audience, situation, diction, language, symbol, and tone and $d a$ 'wa messages by using qualitative-descriptive method, content analysis, and comparative analysis with English Poetry theory and Islamic $d a$ 'wa concept. The analysis shows that both lyrics are Islamic love lyric poetry that delivers love messages and Islamic messages at the same time, namely searching and finding the true and highest love as the true path for happy life in the world and hereafter, namely to remember, pray, and love Allah. The da'wa messages of the lyrics are the action of the Muslim speakers who care and have empathy to the others especially who have problems in life and try to remind lapsed fellow Muslims or other people in general back into the faith and to call, invite, persuade, pray to Allah as the God of Islam. The da'wa are delivered through song lyric in more relax and playful medium as part of daily life of "Muslim Pop".
\end{abstract}

Keywords: Da'wa, Nasyid, English Love Lyric, Poetry, Southeast Asia.

\section{INTRODUCTION}

In Southeast Asia, nasyid groups and their song lyrics have been studied by a number of scholars, however, the English nasyid lyrics are not their focus of researches. On the other hand, the English nasyid lyrics cannot be neglected because of its reach to international audience. Typically nasyid songs contain Islamic beliefs, values, teachings, morals, or messages [1, p. 281] Therefore, nasyid songs are identical with religious messages, but not for their love songs.
In fact, like many other pop singers, nasyid groups also have love songs. They also voice Islamic messages through love songs, like what are done by Raihan and Snada as the icons of Southeast Asian nasyid groups. In several studies, a number of scholars have studied nasyid in Southeast Asia particularly in Malaysia and Indonesia including Raihan and Snada specifically or partially( [2]; [3]; [4]; [1]; [5]; [6]; [7]; $\&$ [8]). They observed nasyid groups related to its context, music, media, culture, politic, and performing art studies as well as Islamic studies, but not specifically examining the lyrics in literary studies in order to understand more on its content or meaning. Furthermore, there has been no research on English nasyid love song lyrics in Southeast Asia, therefore this research tries to examine English nasyid love lyrics in order to understand more on its meanings and its da'wa (invitation, religious call, summons) messages, particularly through Raihan and Snadaes English love lyrics.

Barendregt and Zanten [2] note that originally the term "nasyid" is from Arabic word of "annasyid" (lecture or reverberation), which means ,singer of a religious songee. Musically, it refers to a song genre, popular in Malaysia in the 1980s, used as media of $d a$ 'wa (Islamic preaching) and in Indonesia, it became popular in 1990s especially in pesantren (Islamic schools), mosques, universities, and high schools [2, p. 78]. Nasyid known as a cappella music group were popularised by commercial television (Rakhmani, 2016, p. 52). During Ramadhan month, it becomes annual period of extensive exposure of nasyid groups in many media, like Raihan in Malaysia [1, p. 279].

In Southeast Asia, nasyid is popular, especially in Malaysia and Indonesia. It becomes part of the mainstream and music industry in the two countries( [8, p. 116]; [6, p. 214] \& [1]). Rasmussen[4] called nasyid movement as the pan-Southeast Asian phenomenon[4, p. 115]. Raihan from Malaysia and Snada from Indonesia are not only famous and successful in their respective countries but also in other countries, especially in Southeast Asia, regularly featured on television and received international acclaim ([6, pp. 209210]; [7, p. 53]; and [2, pp. 400-401]). Raihan is called as the icon of Malaysian nasyid group and Snada is called as the icon of Indonesian nasyid group[9]. Both of them are also classified as musicians whose music is always identified as Muslim, as current Muslim pop stars [5, pp. 86-87]. Raihan 
is also called as the most famous of early modern nasyid artists with their debut album as Malaysia's most successful sales since its release in 1996 listed in the Malaysian Book of Records as the "fastest selling album" of all time( [8, p. 116] $\&[6$, p. 209]). Furthermore, Raihan's success has built a large fan base as "Muslim Pop" commodity for all age groups [1, p. 279]. Therefore, it is important to do see further in their lyrics.

Raihan from Arabic word literally means "Fragrance of Heaven". The group was first formed in 1996. They are originally composed of five male members. The member formation has changed several times, but they still exist up to now with all four male members (www. raihanofficial.com). Meanwhile, Snada is literally an abbreviation of "Senandung Nada dan dakwah" (humming a melody and Islamic preaching). Snada first album was released in 1995. Originally they were composed of seven male members but then the member formation has changed few times and they still exist up to now with five male members [9].

The success of Raihan and Snada have influenced the emergences of new nasyid groups in their respective countries and neighboring countries ([1, p. 279]; [4, p. 166]; [6, pp. $209 \& 212-213] \&$. It can be said that many Muslims realized that music is a powerful tool for communication to share Islamic messages of peace. For Raihan, music and song are the media for conveying something easier that is for preaching religious values of tolerant Islam to the youth to get closer to God ( [10] \&. For Snada, they created the group for becoming munsyid (singer of nasyid) for da'wa [9]. Barendregt also said that many Indonesians believe that the emergence of nasyid has a positive impact on young adults "who are often deemed at risk because of a decline in society"s moral values" [3, p. 176]. Furthermore, in Malaysia, Raihan"s success also inspired other Western recording companies to publish their own nasyid groups ( [1, p. 279] \& [8, p. 116]). As a result, it increases the numbers of Muslim artists on the commercial market of the mainstream Western music scene [1, p. 281].

Nasyid songs nowadays are more "pop". According to Erwin Snada, in the past nasyid songs are in Arabic that contain about jihad, but nowadays they also contain crucial condition of society, love theme, religious humanism issues that fit Indonesian society, and inspiration from daily issues. Nasyid music is typical of a capella (by singers who perform without any kind of musical backing) [9]. Nowadays they also performed with a wide variety of musical styles and instrumental arrangements [1, p. 272]. Raihan and Snada also include hip-hop, urban, beatbox, and other forms of current popular music ( [3, p. 244] \& [9]). Besides that, today nasyid songs in Southeast Asia mainly use national languages instead of Arabic ([2, p. 400]; [1, p. 272], and [7, p. 52]). Raihan's songs are mainly in Malay language meanwhile Snada's songs are mainly in Indonesian language, but they also use English and other languages, like Snada that have Mandarin, Japanese, and English songs [2, pp. 400-401]. This is because, Snada created lyrics in English to reach a youthful public with a global awareness and for International audience [11, p. 400]. Furthermore, Raihan marketing are also particularly for the Muslim world [1, p. 279]. In other words, by using English, they try to connect audience across languages for a wide global reach. Therefore, studying more on Southeast Asian English nasyid song lyrics are important particularly its contents related to see its Islamic $d a$ 'wa messages.

According to Encyclopedia of Islam[12, p. 177], Daawa' (Arabic: invitation, religious call, summons) (also dawa, dawat, or dakwah) is "a term that has acquired a number of meanings in the history of Islam, but it is mainly thought of as religious outreach for purposes of conversion or bringing lapsed Muslims back into the faith". Specifically, according to Encyclopedia of Islam and the Muslim World [13, pp. 170171], the word da'wa has several meanings, "such as call, invite, persuade, pray, invoke, bless, demand, and achieve" and "theologically, da'wa refers to the call of God to Islam..." furthermore "conversely $d a$ 'wa refers to the human call directed to God in (mental) prayer or invocation."

Raihan and Snada only have some English song lyrics. From all albums of Snada there are only four English song lyrics sung by Snada and from all albums of Raihan, there are seven English song lyrics sung by Raihan. This research focuses on their English love song lyrics, entitled "Bonds of Love" by Raihan and "Highest Love" by Snada. These two lyrics have similar theme, which is about the expressions of religious love. Specifically, the objectives are to understand and explain the content and meanings of the two lyrics through some elements of poetry namely meaning \& idea, form, speaker (point of view), listener/audience, situation, diction, language, symbol, and tone and the comparison of the two lyrics to see the similarities and differences and finally reveal the $d a$ 'wa messages. Furthermore, it is hoped that this study can contribute to the study of nasyid, Islamic song lyrics, and English love lyric poetry, as well as the studies of $d a$ 'wa in music and song lyrics in Southeast Asia, particularly in Malaysia and Indonesia, by examining its lyrics by content analysis. This is also to contribute the previous studies that did not focus on the English nasyid love song lyrics and there has been no research before specifically on Raihan and Snadaees English love song lyrics.

\section{METHOD}

The primary data of this research are English nasyid love song lyrics, namely "Bonds of Love" (from the 2001 album) by Raihan from Malaysia and "Highest Love" (from the 1991 album) by Snada from Indonesia. Additionally, this study also uses other sources and previous researches on the studies of nasyid, Raihan, and Snada as well as lyric, poetry, and $d a$ 'wa in order to understand and discuss the topic comprehensively.

English poetry theory and $d a$ 'wa concept are used to understand, examine, and analyze the English lyrics. In English poetry studies, the lyric is one of the types of poetry [14, pp. 62-63]. The term lyric is originally a poem to be sung and it also has another meaning that refers to a relatively short poem expressing the thoughts, feelings, personal 
emotion, emotional conceptions of the writer or a single speaker ([15, p. 10]; [14, pp. 62-63]; [16, p. 1xxx]; and [17, p. 496]). Furthermore, technically, analyzing song lyrics as poetry separates the words temporarily from their music $[15$, p. 163]. To understand the lyric fully needs to understand what the lyric "says". Therefore, the analysis of the lyrics as the main data to get its meaning is by using Poetry theory through examining its words from the perspectives of some elements of poetry namely meaning \& idea, form, speaker (point of view), listener/audience, situation, diction, language, symbol, and tone (see the elements of poetry on [18]; [16]; \& [14]) and analysing $d a^{\prime} w a$ messages by using the $d a$ 'wa concept. Furthermore, to understand and explain song lyric, in this case is by using qualitative-descriptive approach with content analysis, which is close reading of a text that involves interpretation into new analytical narratives $[19$, p. 23] and comparative analysis of the two lyrics in order to understand, explain, and concluding the contents, meanings, and $d a$ 'wa messages including its similarities and differences.

\section{RESULT AND DISCUSSION}

Based on the form or arrangement of lines, both of the lyrics of Raihan"s "Bonds of Love" and Snada"e "Highest Love" have different line arrangement. The "Bonds of Love" contains 5 stanzas that consist of 23 lines. The stanzas consist of 6, 6, 2, 2, and 7 lines in chronological order from the first to the last stanza. Meanwhile the "Highest Love" has 9 stanzas that consist of 27 lines. The stanzas consist of $2,4,4,4,3,2,4$, and 4 lines in chronological order from the first to the last stanza. Therefore, these are not fixed form of the stanza, called free verse because each stanza does not consist the same number of lines, in other words, the lyrics do not use fixed metrical pattern in delivering its meaning and messages.

Both of the lyrics indicate a similar idea, which is about love. The word "love as the central point is not only mentioned in the title, but also in the body of both lyrics several times. The "Bonds of Love" mentions three times (7, $10, \& 12)$. While "Highest Love" mentions the word „lovee in every stanza and the total is twenty-nine times in the whole stanzas. Besides that, both of the lyrics also use repetition for the words "Allah" and "You"e or „He" that also refer to Allah. The "Bonds of Love" mentions the word „Allah" four times and "You two times. On the other hand, the "Highest Love" mentions ,Allah" two times and the pronoun „He $\mathrm{He}^{\mathrm{ec}}$ two times to also mention Allah. The use of the words „Allah" , ,You and, $\mathrm{He}^{e e}$ is as the object of love. In short, the use of these repetition words adds the main idea of the lyrics that is to „love Allah ${ }^{\text {ee }}$ This is also one of the messages of $d a$ 'wa, to invite or call to love Allah.

Overall, the "Bonds of Love" expresses the phenomena of love, the need of love, the various feelings and experiences of love, and finally the finding of the true eternal love for happiness and peace in life and for the guidance of life that is the love and pray to Allah as the God. Specifically, the lyric is written in first person point of view speaker who talks directly to the second person ,you ${ }^{e e}$ and cares to other people's feelings and problems who are „sad ${ }^{e e}(1)$, „bad condition (2), ,someone leave you behind ${ }^{\text {ee }}$ (3), and „,broken hearte $^{\text {ee }}$ (9), by comforting, giving advice, persuading, and encouraging to come, remember, pray, and love Allah as the true love for happiness, "Only falling in love/ With Allah..../ The bonds of love survive/" (10-12) and as a guidance of life, "Come to Allah you'll never fail/ The truth"s so close it shall prevail/" (15-16). This can also be called as part of the $d a$ 'wa messages. The speaker also encourages to struggle and face the obstacles in finding the true love, happiness, and the right path, "No mountain too high when there's a will/ No river too wide believe there's a way/" (13-14). These show that the listener or audience are other fellow Muslims or other people in general. In the end by ,praying to Allah"e, the speaker shows the attitude of surrender to Allah as His follower and seeking guidance for the right path of life for happiness, as it is written in the last stanza:

O Allah, we belong to You

And everything we do

We do it all for You

O Allah, always by our side

Guiding us to the light

Everything shines bright

No matter day or night

The "Highest Love" is also written in first person point of view speaker who talks to the second person ,you ${ }^{\text {ee }}$ that the speaker shares his/her views and experiences of love, having love, the need of love, various kinds of emotion and feelings from love, and finally in realizing and finding the true and highest love, which is to love Allah as the God as the islamic message of $d a$ ' $w a$ "And then I realize about love/ This would be the true one, the highest love" (18-19). „Love "e here is described in irony where love not only makes good, such as "happiness" (3 \& 13), "peace" (3 \& 13), "threw loneliness out" (4), "beautiful" (5), "wonderful" (6), but also bad, such as "madness" (11), "pain" (11, 12, \& 14), "sadness" (12 \& 14). The lyric also mentions the word heart" six times $(3,4$, $11,12,13, \& 14)$. The repetitions highlight the heart as the place of all feelings caused by love and also as a symbol of life with many problems that need attention for the happiness of life. Love as a symbol of life is also shown in the first stanza , "There"s a thing we all have that is love/ And that thing we all need, that is love" (1-2) and love as the key to find God as the source of true and highest love and happiness, "This is the true love this is the highest love/ Love your god love your god love Allah" (22-23), and "You will be happy on the earth and heaven forever/Just for Allah" (2627). Here, the listener or audience can be assumed as the other fellow Muslims, "Love your god love your god love Allah" (23). In the end, the speaker also persuades the others to come, remember, and love God and getting the true love and happiness that is by loving Allah as the God, also as the act of $d a$ 'wa, as it is written in the last stanza;

Then he will give you the really love

Then he will send you people with true love

You will be happy on the earth and heaven forever 
Just for Allah

Additionally, both of the lyrics tone are religious, persuasion, solemn, and reassure to remember, pray, and love Allah and comforting and giving empathy attitude toward someone's sorrow, sadness, problem and related to the experiences of love and all good and bad feelings caused by love. Then, both of the tone lyricse ending show optimistic, faithful, and happy feeling for having the feeling of love, finding happiness and the true love, which is to love Allah as the God. What is more, the main idea or the theme of both lyrics are similar, namely about love, specifically searching and finding the true and highest love to Allah and seeking for guidance for happiness in life in the world and hereafter.

Finally, both of the lyrics deliver love messages and Islamic messages at the same time. The Islamic da'wa messages can be seen through the whole meanings and ideas of both lyrics, language, and diction like the word „Allah" and some other words; in the "Bonds of Love" such as "Only falling in love/ With Allah..../ The bonds of love survive" (10-12), "Come to Allah you'll never fail" (15), and the last stanza, "O Allah, always by our side/ Guiding us to the light/..." (20-21). The "Highest Love" also has some keywords, such as "This is the true love this is the highest love/Love your god love your god love Allah" (22-23) and the last stanza, ".../ You will be happy on the earth and heaven forever/ Just for Allah" (26-27). The da'wa messages of the lyrics can also be seen through the attitudes, tone, and situation of the Muslim speakers to the listeners/audience. In other words, it is done by reminding and bringing fellow Muslims back into the faith and by calling, inviting, persuading, and praying to Allah. These $d a$ 'wa messages can be addressed to other fellow Muslims, but also can be for the public in general, as part of the $d a$ 'wa (invitation or religious call).

In term of $d a$ 'wa, in this context both Raihan and Snada as "Muslim Pop" musicians softly use English love songs for their da'wa in delivering, reminding, preaching, and spreading Islamic messages. Although the lyrics use poetic elements like connotation, irony, symbol, and diction, the lyrics are not too difficult to understand and they are more relax and playful because they are delivered by music and in not difficult words of English so that they can be understood by the wider international audience. Finally, songs become part of daily life and as it said by Mustafa, "in the modern Muslim world, poetry [including lyric] remains a powerful medium for telling stories of love, faith, and struggle" (Mustafa, 2011, 285).

\section{IV.CONCLUSION}

Both of Raihan and Snada's English love song lyrics are also called short poems in poetry studies that express personal thoughts, feelings, and voices of individual speakers about love to Allah and da'wa messages. The two lyrics can be classified as religious lyrics, called Islamic lyric poetry. Both of its speakers can be said as Muslims or Allah's followers who are searching and finding happiness of life and the true love, that is by remembering, praying, and loving Allah with its listeners or audience as other fellow Muslims or can also for other people in general. The meanings of the lyrics are delivered through some elements of poetry and comparatively, both also show similar main ideas, form, speaker (point of view), listener/audience, situation, diction, language, symbol, tone, and $d a$ 'wa messages. In other words, both of the English nasyid love song lyrics have love theme but they are still with Islamic identity, which is religious love to Allah and da'wa messages.

Finally, this research contributes to the study of nasyid in particular, to understand and reveal the meanings of English nasyid love song lyrics in Southeast Asia in literary studies that have not been studied before. This research is also hoped that this Islamic love lyric research can contribute to the variety of research and the development of the study of English lyric and poetry especially in relation to Islam and literature or Islamic studies and literary studies as an interdisciplinary studies and also for further studies. This is because English lyric Poetry studies in relation to Islam and $d a$ 'wa have not been discussed much.

\section{REFERENCES}

[1] S. Mustafa, "Women Writers.," in In Felicity Crowe, et al. (eds). Islamic Beliefs, Practices, and Cultures., New York: Marshall Cavendish Reference, 2011.

[2] B. Barendregt and W. van Zanten, Popular Music in Indonesia since 1998, in Particular Fusion, Indie and Islamic Music on Video Compact Discs and the Internet. Yearbook for Traditional Music, vol. 34: 67-113. 2002.

[3] B. Barendregt, Cyber-nasyid. Transational Soundscapes in Muslim Southeast Asia. In Todd Joseph miles Holden and Timothy J. Scrase (eds).Medi@sia. Global media/tion in and out of context. New York: Routledge, 2006.

[4] A. K. Rasmussen, "Performing Religious Politics: Islamic Musical Arts in Indonesia.," in In John Morgan O "Connell and Salwa ElShawan Castelo-Branco. Music and Conflict., Urbana, Chicago \& Springfield: University of Illinois Press, 2010.

[5] R. A. Sutton, "Music, Islam, and the commercial media in contemporary Indonesia," in In Andwer N. Weintraub (ed). Islam and Popular Culture in Indonesia and Malaysia., New York: Routledge, 2011.

[6] "Seneviratne, Kalinga.," in Countering MTV Influence in Indonesia and Malaysia. Singapore: ISEAS. Snada. (1991). "Highest Love” (song lyric)., .

[7] I. Rakhmani, Mainstreaming Islam in Indonesia, Television, Identity, and the Middle Class. New York: Palgrave Macmillan, 2016.

[8] S. Janmohamed, Generation M: Young Muslims Changing the World. London \& New York: I.B.Tauris, 2016.

[9] P. T. Juniman, . "Nasyid Mengantar Snada Sampai ke Mekkah.," 28May-2017. [Online]. Available:

http://www.cnnindonesia.com/hiburan/20170528015124-227217763/nasyid- mengantar-snada-sampai-ke-mekkah/.

[10] F. Harrison, "UK World: Asia-Pacific Islamic pop storms Malaysia.," 18-May-1999. [Online]. Available: http://news.bbc.co.uk/2/hi/asiapacific/347165.stm.

[11] C. Capwell, Music, Modernity, and Islam in Indonesia. In Victoria Lindsay Levine \& Philip, 2015.

[12] J. E. Campo, Daawa. Encyclopedia of Islam. New York: Facts on File, 2009.

[13] R. C. Martin and ed, Da'wa. Encyclopedia of Islam and the Muslim World., vol. I (A-L). New York: Macmillan, 2004.

[14] A. H. Hewitt, Coming to Term with Poetry. Sydney: Scientific Publications, 1965.

[15] X. J. Kennedy and D. Gioia, An Introduction to Poetry, 11th edition. New York: Longman, 2005. 
[16] R. Ellmann and R. O. clair, Modern Poems. An Introduction to Poetry. New York: W.W. Norton \& Company, 1976.

[17] I. Ribner and H. Morris, Poetry. A Critical and Historical Introduction. Chicago, Atlanta, Dallas, Palo Alto, Fair Lawn, N.J.: Scott Foresman Company, 1962.

[18] L. Perrine and T. R. Arp, Sound and Sense An Introduction to Poetry (8th ed.). New York: Harcourt Brace College Publisher, 1992.

[19] Klaus, Content Analysis: An Introduction to Its Methodology. Sage Publications, 2013. 